\title{
Performance evaluation of anaerobic baffled biodigester for treatment of black water
}

\author{
Ligy Philip*, K. Kalaivani, Praveen Rosario, Vamsi Krishna and S. SriShalini \\ Department of Civil Engineering, Indian Institute of Technology Madras, Chennai 600 036, India
}

In this study, the performance of anaerobic baffled biodigester installed in different regions of South India was evaluated for black water treatment. The evaluation was based on the vendors, establishment, impact of different sampling methods (grab and composite sampling) and the application of post-treatment unit. The treatment efficiency of the digester was assessed in terms of removal of organics (biological oxygen demand (BOD), chemical oxygen demand (COD)), total suspended solids (TSS) and pathogens (faecal coliform). The maximum removal rate of $\mathrm{COD}, \mathrm{BOD}$ and TSS was found to be in the range of 70-75\%, 68$80 \%$ and $55-75 \%$ respectively. Variations were observed between the grab and composite samplings with respect to the removal efficiency of organics, solids and pathogens. There was no significant difference in the performances of anaerobic biodigesters installed by different vendors in South India. The application of post- treatment unit such as gravel bed/reed bed after biodigester facilitated the removal of residual organic pollutants and provided better quality outlet water. The results indicated that the performance of anaerobic baffled biodigesters varies based on the number of users, location, usage pattern and the posttreatment unit installed.

Keywords: Anaerobic digestion, biodigester, black water, community toilet, onsite treatment, sanitation.

FAECAL contamination of water resources remains a major concern, especially in developing countries. Almost $99.8 \%$ of deaths in developing countries is due to sanitation, water and hygiene-related problems ${ }^{1}$. Dense black water consists of organic materials, nutrients and pathogens, which constitute high concentrations of chemical oxygen demand (COD), nitrogen and phosphorus. Treatment of black-water through the use of appropriate sanitation systems acts as the primary barrier to prevent the spread of pathogens in the environment. On-site/ decentralized wastewater treatment is used to dispose/ reuse small volumes of wastewater at the same location where it is generated. Such systems are desirable in rural and peri-urban areas which could be single households or groups of dwelling situated in close proximity ${ }^{2}$. Usage of

*For correspondence. (e-mail: ligy@iitm.ac.in) on-site treatment system has several advantages compared to centralized wastewater treatment system, which includes functional simplicity, economic affordability, no need for large-scale pipe network and easy energy recovery $^{3}$. Anaerobic treatment is considered as a promising core technology for recovering resource and energy from source-separated bio-waste such as concentrated black water and brown water ${ }^{4}$.

Septic tank is extensively used as an on-site treatment system for black water because of its low energy consumption, small space requirement and relatively simple reactor design ${ }^{2}$. Septic tanks are capable of removing 20 $50 \%$ of pollutant load in wastewater ${ }^{5}$; their low treatment efficiency is a major concern. Various options practised for on-site treatment of black water are dry pits, twin-pit (leach pit), septic tanks, biodigesters/biotanks, biotank with reed bed treatment, constructed wet lands ${ }^{6}$, packaged treatment units ${ }^{7,8}$, etc. However, it has been reported that the treatment efficiency of these systems is not very high due to the presence of high pollutant concentration. Moreover, most of the existing on-site treatment systems do not have any post-treatment facility to remove residual pollutants or pathogens ${ }^{9}$. Several advanced reactors such as the anaerobic filter reactor $(\mathrm{AF})^{10,11}$, up-flow anaerobic sludge blanket reactor $(\mathrm{UASB})^{12}$, expanded granular sludge bed reactor, anaerobic baffled reactor ${ }^{13}$, membrane bioreactor (MBR) and moving-bed biological reactors (MBBR) have been developed to tackle the challenges of efficient domestic wastewater treatment. However, they are not popular as on-site treatment systems due to the complexity, cost and requirement of skilled personnel for operation and maintenance. Most of the earlier studies, had not justified whether the treatment systems were sustainable or not in terms of energy and economics ${ }^{7,14}$. The conventional on-site system has been widely used for black water treatment in developing countries.

India is lagging behind other countries with respect to environmental sanitation, and it requires newer strategies and targeted inventions with follow-up evaluation ${ }^{15}$. In order to achieve sustainable and less expensive on-site treatment of black water, the Defense Research and Development Organisation (DRDO), India has developed an anaerobic baffled biodigester specifically inoculated with an enriched and bio-augmented microbial consortium. This eco-friendly biodegradation technology was initially designed for human waste disposal for the armed 
forces posted at high altitudes and glaciers. The consortium designed for organic matter degradation was prepared by acclimatization, enrichment and bio-augmentation with psychrophilic microbes collected from Antarctica and low-temperature areas. These microbial consortia break down biodegradable organic matter into methane and carbon dioxide in the absence of oxygen ${ }^{16}$. According to the developers, the microbial consortium was able to work in varying temperatures, i.e. $5^{\circ}-50^{\circ} \mathrm{C}$, and could resist freezing, thawing and temperature fluctuations. DRDO has also reported that these biodigesters have the capability to treat faecal waste to the extent of more than $90 \%$ and inactivate the pathogens during fermentation, rendering the effluent almost free of them. The consortium is being prepared and marketed by various approved vendors. These biodigesters have been installed in large numbers at various regions and facilities in India and elsewhere ${ }^{17}$. However, there are limited studies available on the performance of these anaerobic bioreactors for the treatment of black water ${ }^{14,18}$. Also, anaerobic biodigesters inoculated with specific microbial consortia for the treatment of black water in a long run have not been studied. The field data pertaining to continuous monitoring of biodigesters, the effect of inocula over different regions, and the efficiency of inocula available in the market are also not well reported, though a large number of such units are deployed at various regions in India. Hence, it is essential to carry out performance evaluation of the anaerobic baffled biodigester for the treatment of black water.

The present study evaluated the performance of existing anaerobic baffled biodigesters installed by DRDO licensee vendors (field installations) in different parts of South India. Studies were also carried out to (i) examine the impact of sampling method on evaluating the digester performance, (ii) assess the vendors-based variations on digester performance, (iii) evaluate establishment-based variation on digester performance and (iv) examine the role of post-treatment systems like gravel/reed bed on effluent quality.

\section{Materials and methods}

\section{Site details and analysis}

The anaerobic baffled biodigesters were installed at different locations in India for the treatment of black water. The technology behind this treatment mechanism was developed and promoted by DRDO; various vendors are available in the market for these types of digesters all over India. The basic criterion used for the selection of sites was that the installed biodigesters should have completed one year of operation. In the present study, three different vendors were chosen based on accessibility and institutional pattern. A questionnaire survey was con- ducted to assess the socio-economic aspects and to understand the type of institutions where the units are installed and the number of people using them. Based on accessibility, 13 sites were selected and in-depth composite samplings were carried out once a month to evaluate the performance of the system. In addition to composite sampling, grab sampling was also carried out in five sites, to understand how the sampling methods influence performance evaluation. In some locations, post-treatment units were connected to the biodigesters. Table 1 shows the list of 13 sites and Figure 1 presents their distribution. Table 2 shows the characteristics of the inocula. A detailed description of the biodigester is given in the Supplementary Material (Section 1).

\section{Sampling details and analysis}

Grab sampling was carried out once a month during November 2015 to March 2016. For this, samples were taken from the first compartment of the biodigester. Due to fluctuations observed in the inlet organics and solids concentration every month, composite sampling was planned. Civil modifications were carried out to perform composite sampling, which was carried out once a month from October 2016 to July 2018. Composite samples were taken at regular intervals of $24 \mathrm{~h}$. For flow measurement during composite sampling, offline pipe connections were provided in all the reactors in such a way that the flow directly entered the digester on all days, except the sampling day. On the day of sampling the flow passed through the sampling chamber provided in the inlet and outlet. This was controlled with the help of a valve. Details are provided in the Supplementary Figure 1 . The sampling chambers of all units were cleaned thoroughly $24 \mathrm{~h}$ before composite sampling. The flow rate to the digester was calculated based on the volume of raw water collected in the inlet tank at the stipulated time (24 h).

Samples of raw water, treated water after biodigester, treated water after post-treatment unit and tap water (control) were collected once a month from all the 13 sites. After sampling, the samples were transported to the laboratory and stored at a temperature below $4^{\circ} \mathrm{C}$. The analyses were carried out within $24-48 \mathrm{~h}$ of sample collection. The samples were collected, transported and preserved according to standard methods ${ }^{19}$. The collected samples were analysed for various physico-chemical and bacteriological parameters $(\mathrm{pH}$, total biological oxygen demand (BOD), COD, solids, and faecal coliforms (FC)). All the physico-chemical parameters of influent and effluent samples were analysed according to standard methods ${ }^{19}$. To maintain quality control, the samples were processed in triplicate for wastewater analysis, and standards were run at regular intervals. Hydraulic retention time (HRT) was calculated for all the sites. One-way 
RESEARCH ARTICLES

Table 1. Details of anaerobic baffled biodigester in different regions of South India

\begin{tabular}{|c|c|c|c|c|c|c|c|}
\hline Vendor & Plant & Treatment type & $\begin{array}{c}\text { No. of } \\
\text { users/day }\end{array}$ & $\begin{array}{c}\text { Reactor } \\
\text { capacity } \\
\left(\mathrm{m}^{3}\right)\end{array}$ & $\begin{array}{c}\text { Inflow } \\
\text { rate }(1 / d)\end{array}$ & $\begin{array}{l}\text { Outflow } \\
\text { rate }(1 / d)\end{array}$ & $\begin{array}{l}\text { Hydraulic } \\
\text { retention } \\
\text { time (d) }\end{array}$ \\
\hline \multirow[t]{2}{*}{ A } & Tirumalai Nagar Park, Chennai & Bio-digester & $25-30$ & 2 & 340 & 280 & 5.88 \\
\hline & Rajiv Nagar Park, Chennai & Bio-digester & $25-30$ & 2 & 289 & 220 & 6.92 \\
\hline \multirow[t]{6}{*}{ B } & Company in Jeedimetla, Hyderabad & Bio-digester & 300 & 10 & 4000 & 3260 & 2.5 \\
\hline & Company in Bengaluru & Bio-digester & $15-20$ & 0.8 & 220 & 184 & 3.63 \\
\hline & School in Kadapa (site 1) & Bio-digester & $30-35$ & 1 & 190 & 120 & 5.3 \\
\hline & School in Chinnakomerla village, Kadapa (site 2) & Bio-digester & $100-120$ & 1 & 257 & 170 & 3.9 \\
\hline & School in Talamanchipatnam, Kadapa (site 3) & Bio-digester & $40-45$ & 1 & 160 & 95 & 6.3 \\
\hline & Sedarapet, Puducherry & Bio-digester & $120-150$ & 8 & 1100 & 900 & 7.27 \\
\hline \multirow[t]{5}{*}{$\mathrm{C}$} & Pambanbusstand, Ramanathapuram & Bio-digester + gravel bed & 100 & 8 & 2100 & 1450 & 3.8 \\
\hline & Ramanathapuram (Collectorate Office) & Bio-digester + gravel bed & $50-60$ & 8 & 1750 & 1560 & 4.6 \\
\hline & Kappalore community toilet block, Madurai & Bio-digester + sand filter & $100-150$ & 8 & 750 & 680 & 10.6 \\
\hline & Paramathy, Karur & Bio-digester + reed bed & $70-100$ & 8 & 1750 & 1234 & 4.57 \\
\hline & Kulathur village, Coimbatore & Bio-digester + gravel bed & $80-100$ & 8 & 1860 & 1150 & 4.3 \\
\hline
\end{tabular}

Table 2. Characteristics of vendor A inoculum, vendor B inoculum and control anaerobic sludge

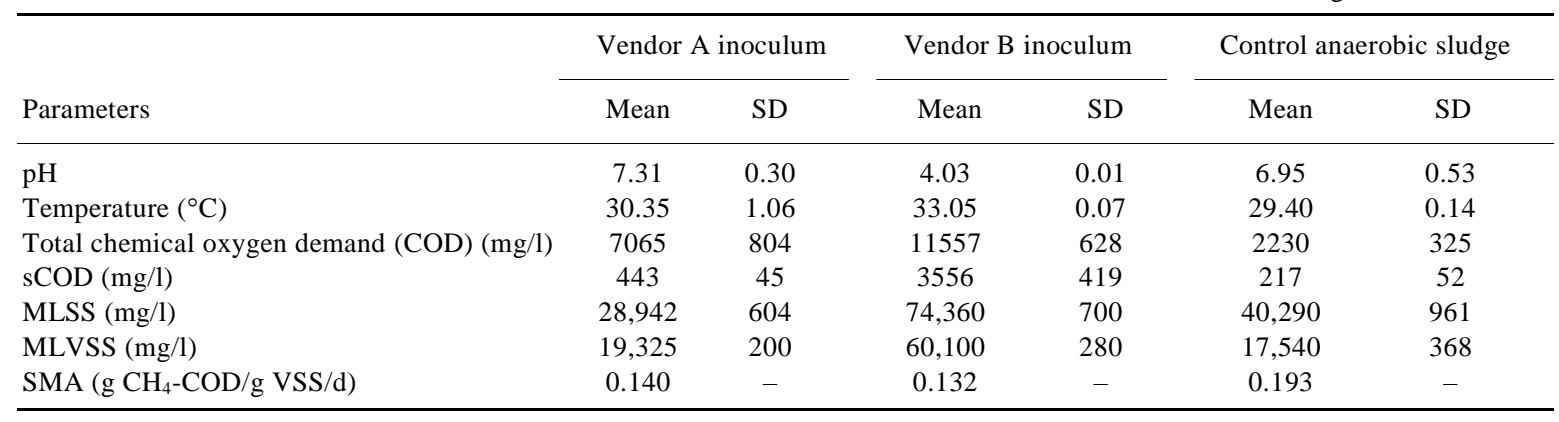

sCOD, soluble COD; MLSS, mixed liquor suspended solids; MLVSS, mixed liquor volatile suspended solids

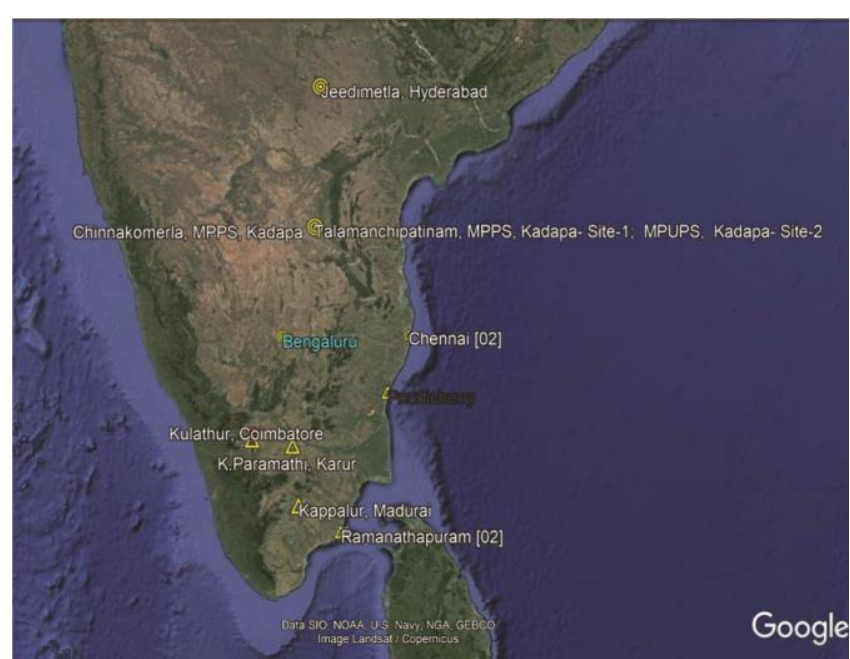

Figure 1. Distribution of 13 anaerobic baffled biodigesters in South India.

analysis was performed to determine whether the biodigesters procured from different vendors showed any variation in treatment efficiency. Detailed description of the methodology adopted for each parameter is given in the Supplementary Material (Section 2).

\section{Results and discussion}

\section{Black water characteristics}

The performance of anaerobic baffled biodigester installed in 13 different locations was assessed. In order to understand whether the sampling strategy causes any variation in influent and effluent quality, five sites were selected (i.e. Karur, Madurai, Ramanathapuram, Thirumalai Nagar and Rajiv Nagar) based on accessibility to carry out grab and composite sampling. Tables 3 and 4 show the average raw water and treated water concentrations of organics, solids, faecal coliforms and nutrients for grab and composite sampling. The average treated water $\mathrm{pH}$ was observed to be in the range 6.5-7.8, which falls within the recommended values for anaerobic digestion $^{20}$, signifying no excessive accretion of organic acids in the biodigester. The average BOD to COD ratio of raw water was around 0.69 , indicating that biological treatment of raw water is possible ${ }^{21}$. During grab sampling, the average raw water concentration of BOD, COD and TSS was found to be in the range $127-778,72-781$ and $155-561 \mathrm{mg} / \mathrm{l}$ respectively. In the case of composite sampling, the average concentration of raw water BOD, COD and TSS was 158-595, 283-812 and 41-920 mg/l 
Table 3. The physico-chemical characteristics of both influent and effluent during grab sampling

\begin{tabular}{|c|c|c|c|c|c|c|c|c|}
\hline \multirow[b]{3}{*}{ Field units } & \multicolumn{8}{|c|}{ Concentration } \\
\hline & \multicolumn{2}{|c|}{$\begin{array}{c}\text { Biological oxygen } \\
\text { demand (BOD) }(\mathrm{mg} / \mathrm{l})\end{array}$} & \multicolumn{2}{|c|}{$\begin{array}{c}\text { Chemical oxygen } \\
\text { demand (COD) }(\mathrm{mg} / \mathrm{l})\end{array}$} & \multicolumn{2}{|c|}{$\begin{array}{c}\text { Total suspended } \\
\text { solids (TSS) (mg/l) }\end{array}$} & \multicolumn{2}{|c|}{$\begin{array}{l}\text { Faecal coliform } \\
\text { (FC) }(\mathrm{MPN} / 100 \mathrm{ml})\end{array}$} \\
\hline & Inlet & Outlet & Inlet & Outlet & Inlet & Outlet & Inlet & Outlet \\
\hline Karur & $330 \pm 246$ & $73 \pm 42$ & $899 \pm 383$ & $358 \pm 199$ & $635 \pm 448$ & $208 \pm 149$ & $3.43 \mathrm{E}+8$ & $7.6 \mathrm{E}+4$ \\
\hline Madurai & $303 \pm 164$ & $90 \pm 49$ & $933 \pm 889$ & $264 \pm 194$ & $613 \pm 514$ & $305 \pm 392$ & $3.98 \mathrm{E}+08$ & $2.6 \mathrm{E}+5$ \\
\hline Tirumalai Nagar & $654 \pm 284$ & $130 \pm 114$ & $528 \pm 236$ & $230 \pm 122$ & $536 \pm 493$ & $188 \pm 194$ & $8.1 \mathrm{E}+7$ & $6.5 \mathrm{E}+4$ \\
\hline Rajiv Nagar & $380 \pm 209$ & $141 \pm 96$ & $668 \pm 252$ & $309 \pm 106$ & $513 \pm 508$ & $162 \pm 106$ & $4.1 \mathrm{E}+8$ & $2.8 \mathrm{E}+4$ \\
\hline Kadapa 1 & $296 \pm 85$ & $85 \pm 27$ & $819 \pm 327$ & $313 \pm 150$ & $279 \pm 255$ & $100 \pm 69$ & $8.7 \mathrm{E}+7$ & $7.5 \mathrm{E}+4$ \\
\hline Kadapa 2 & $275 \pm 165$ & $82 \pm 44$ & $526 \pm 388$ & $220 \pm 154$ & $283 \pm 158$ & $136 \pm 69$ & $2.74 \mathrm{E}+8$ & $8.1 \mathrm{E}+4$ \\
\hline Kadapa 3 & $357 \pm 197$ & $97 \pm 39$ & $1047 \pm 614$ & $486 \pm 360$ & $396 \pm 297$ & $176 \pm 80$ & $3.2 \mathrm{E}+7$ & $1.6 \mathrm{E}+4$ \\
\hline Bengaluru & $466 \pm 185$ & $213 \pm 84$ & $1064 \pm 727$ & $419 \pm 288$ & $374 \pm 228$ & $209 \pm 102$ & $4.3 \mathrm{E} 7$ & $1.5 \mathrm{E}+4$ \\
\hline Hyderabad & $540 \pm 216$ & $146 \pm 53$ & $1801 \pm 933$ & $589 \pm 389$ & $655 \pm 240$ & $424 \pm 179$ & $6.1 \mathrm{E}+8$ & $2.12 \mathrm{E}+4$ \\
\hline Ramanthapuram (PBS) & $549 \pm 191$ & $152 \pm 49$ & $1164 \pm 298$ & $394 \pm 101$ & $985 \pm 279$ & $211 \pm 130$ & $1.19 \mathrm{E}+8$ & $2.2 \mathrm{E}+5$ \\
\hline Ramanathapuram (CO) & $549 \pm 191$ & $152 \pm 49$ & $1572 \pm 749$ & $450 \pm 174$ & $1077 \pm 331$ & $218 \pm 191$ & $3.62 \mathrm{E}+8$ & $5.7 \mathrm{E}+5$ \\
\hline Puducherry & $466 \pm 185$ & $213 \pm 84$ & $1764 \pm 917$ & $770 \pm 353$ & $1101 \pm 5$ & $532 \pm 18$ & $2.57 \mathrm{E}+8$ & $2.11 \mathrm{E}+05$ \\
\hline Coimbatore & $662 \pm 279$ & $198 \pm 89$ & $2158 \pm 192$ & $790 \pm 215$ & $762 \pm 22$ & $233 \pm 55$ & $1.07 \mathrm{E}+8$ & $1.01 \mathrm{E}+5$ \\
\hline
\end{tabular}

Table 4. Physico-chemical characteristics of influent and effluent during composite sampling

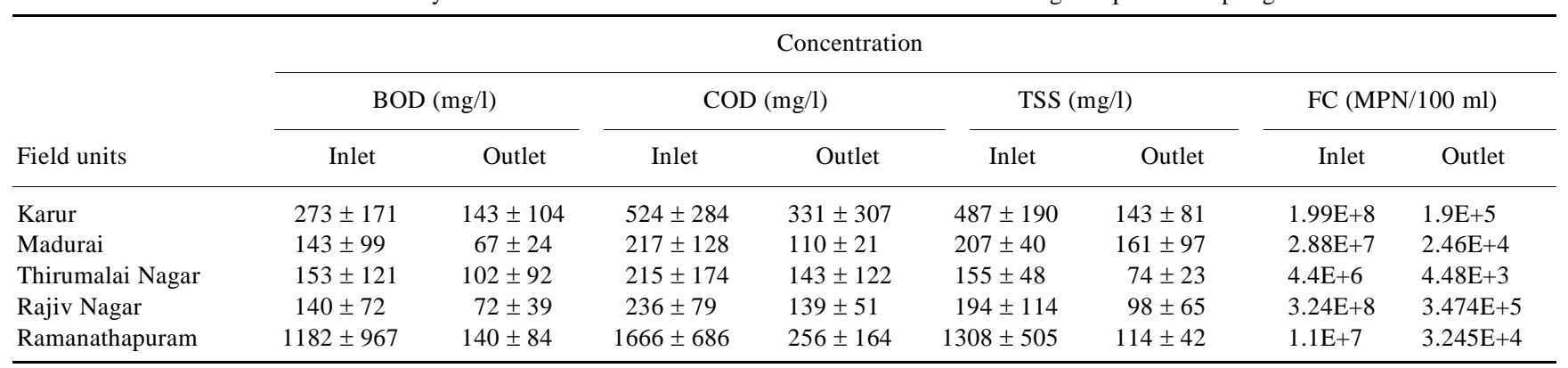

respectively. The higher concentration of organics and solids while carrying out grab sampling clearly indicates that grab sampling from the first compartment is not a representative method for sample collection for the anaerobic biodigester. However, in composite sampling, the wastewater was held for about $24 \mathrm{~h}$ in a collection chamber, and thorough mixing was also done prior to sample collection. The black water characteristics of composite sampling in this study were similar to those obtained by Sharma and Kazmi ${ }^{11}$. On the contrary, it was much lower than those obtained by Kujawa-Roeleveld and Zeeman ${ }^{22}$ and Hocaoglu et al. ${ }^{23}$. This is because the reactors (UASB septic tanks) used in their studies were connected to two vacuum toilets, using approximately 1 litre water to flush the waste. This volume is comparatively lower than the usage of flush water (5-6 litre) in the present study. As a result, the strength of wastewater in the above studies was high. Kujawa-Roeleveld and Zeeman ${ }^{22}$ reported that the influent COD concentration for lower flush water consumption was $9503 \pm 6460 \mathrm{mg} / \mathrm{l}$ (one time faeces and five times urine as produced by one individual per day), which is nine times higher than the value obtained in the present study. Hence, flush water usage in toilets has a significant influence on black water characteristics. The concentration range of FC in all sites was $10 \mathrm{E}+6-10 \mathrm{E}+$
7MPN/100 ml. Similar range of $\mathrm{FC}(6.6 \mathrm{E}+7-3.3 \mathrm{E}+7$ MPN/100 ml) was observed by Sharma and $\mathrm{Kazmi}^{8}$ in black water generated at a residential school in Uttarakhand, India and $1.7 \mathrm{E}+6 \pm 1.1 \mathrm{E}+6 \mathrm{MPN} / 100 \mathrm{ml}$ in raw black water treated in a laboratory scale treatment system.

\section{Performance of anaerobic baffled biodigester based on grab and composite sampling}

Table 4 presents the average effluent quality of the biodigester during composite sampling. The pollutant (organic) load was reflected in terms of BOD, COD and TSS. The average effluent COD concentration in the biodigesters with regular users was in the range 220$400 \mathrm{mg} / \mathrm{l}$, which is significantly less than the influent concentration. Figure $2 a$ shows the overall removal efficiency of the biological treatment. The biodigester with regular number of users showed higher COD, BOD and TSS removal efficiency in the range $70-75 \%, 68-80 \%$ and $60-80 \%$ respectively. COD and BOD removal was mostly governed by anaerobic microbial activity in which four different groups of microbes (fermentative, syntrophic, acetogenic and methanogenic bacteria) degraded organic matter into $\mathrm{CO} 2$ and methane through 

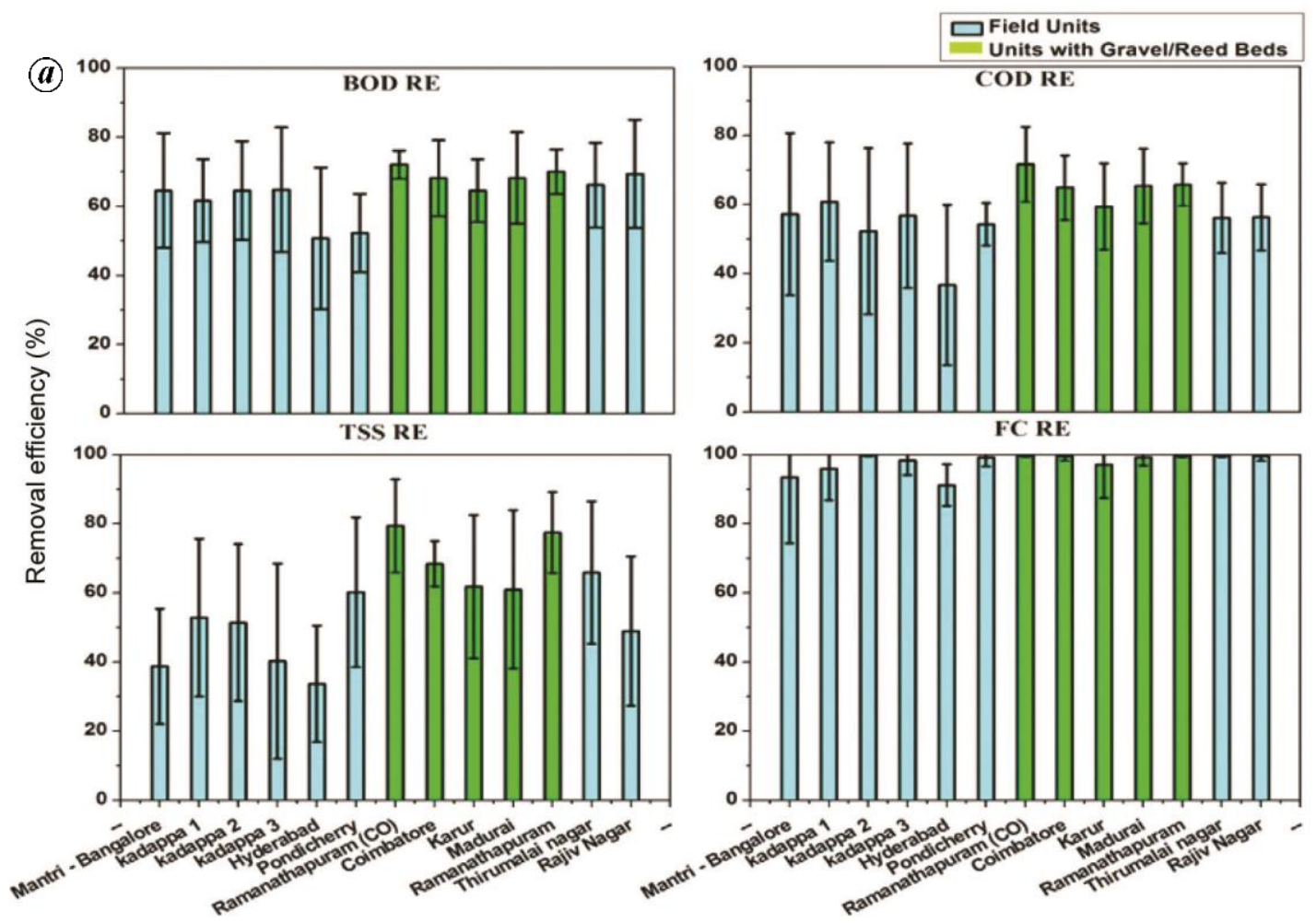

(b)
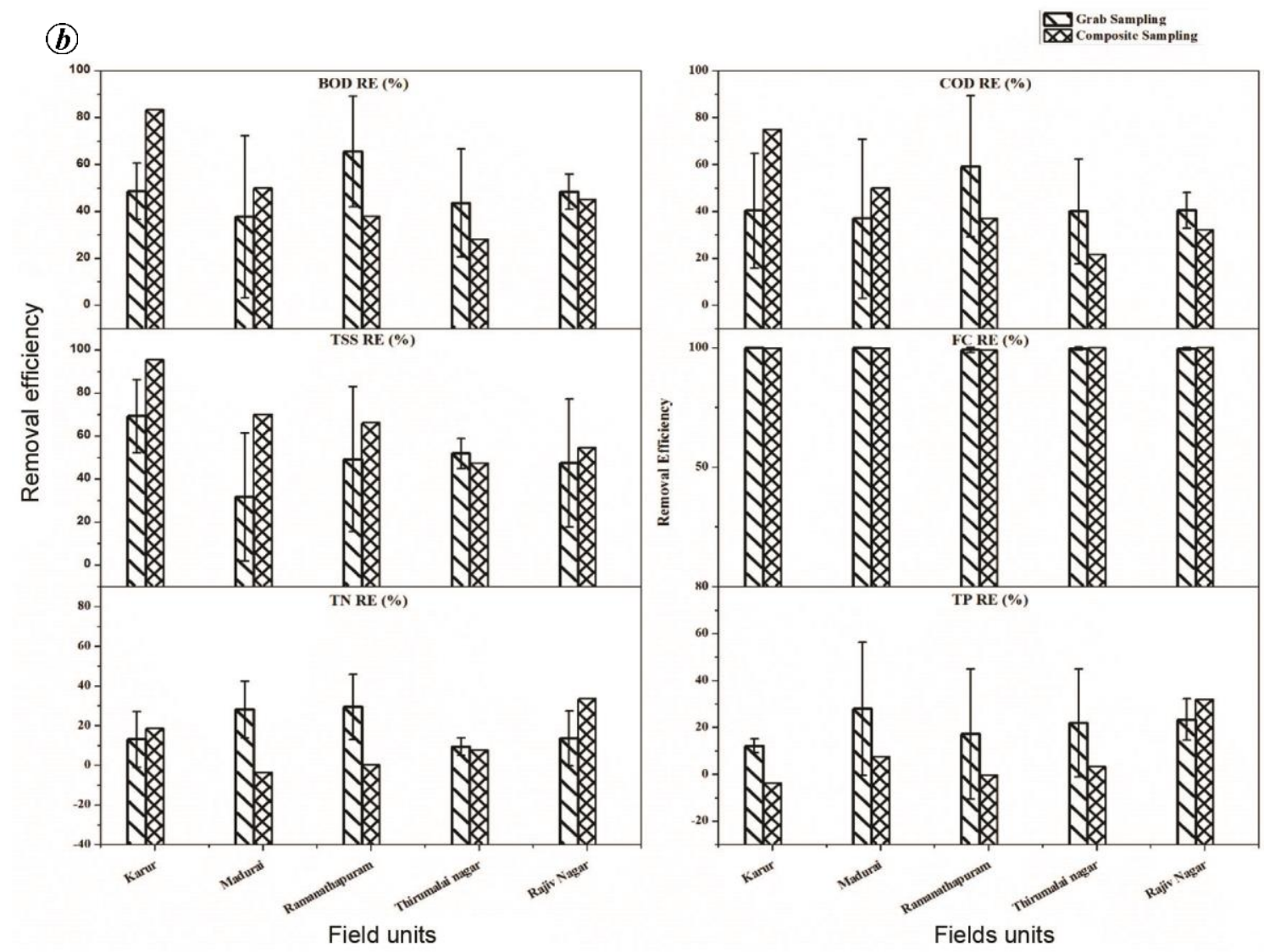

Figure 2. Average removal efficiency of biological oxygen demand (BOD), chemical oxygen demand (COD), total suspended solids (TSS) and faecal coliform (FC) of anaerobic baffled biodigesters. $\boldsymbol{a}$, At different locations in South India; $\boldsymbol{b}$, During grab and composite sampling. 
(C)
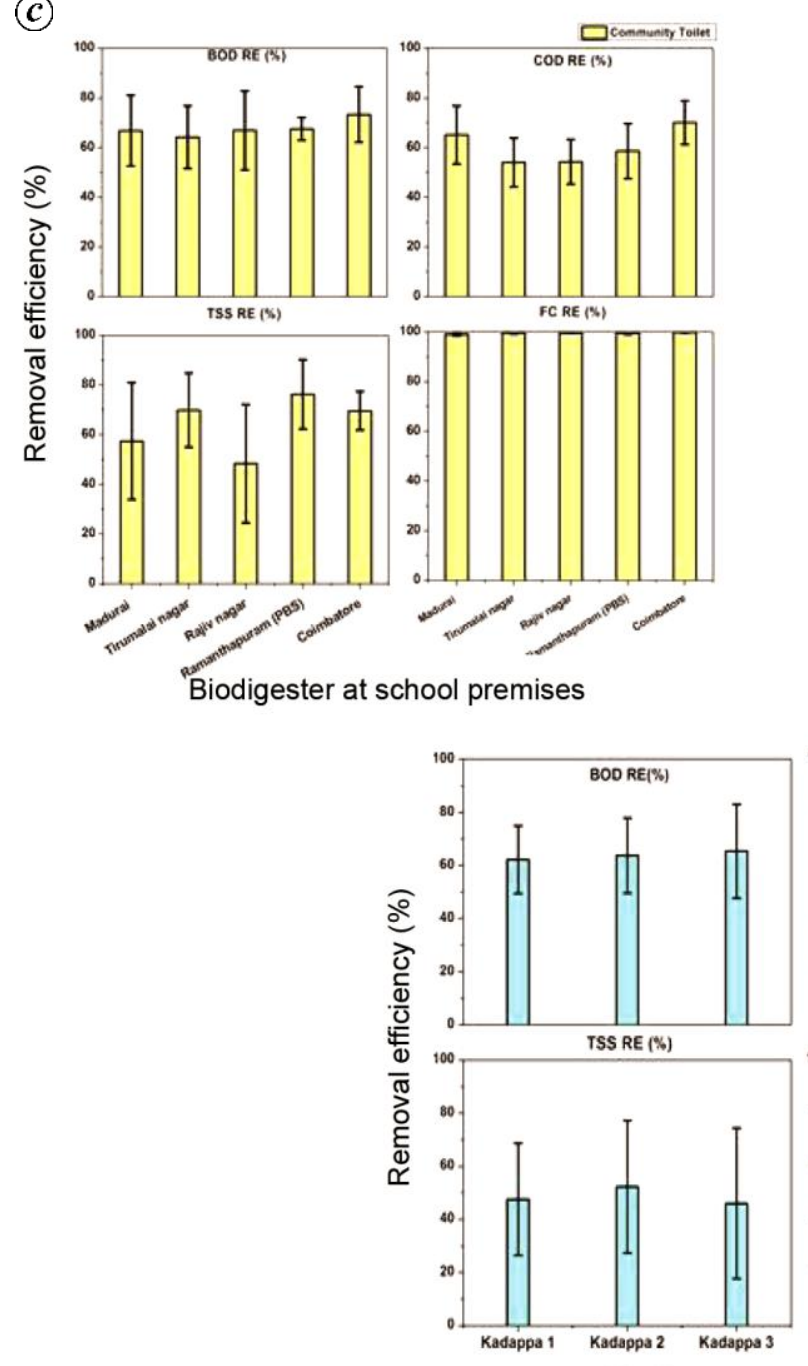

Biodigester at school premises

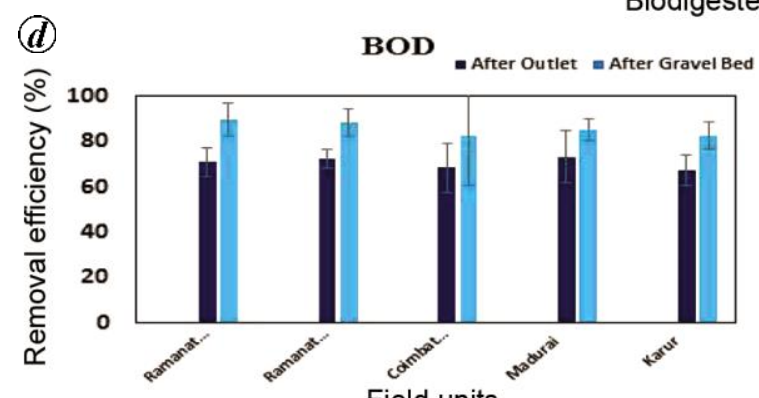

Field units

COD - After Outlet $=$ After Gravel Be

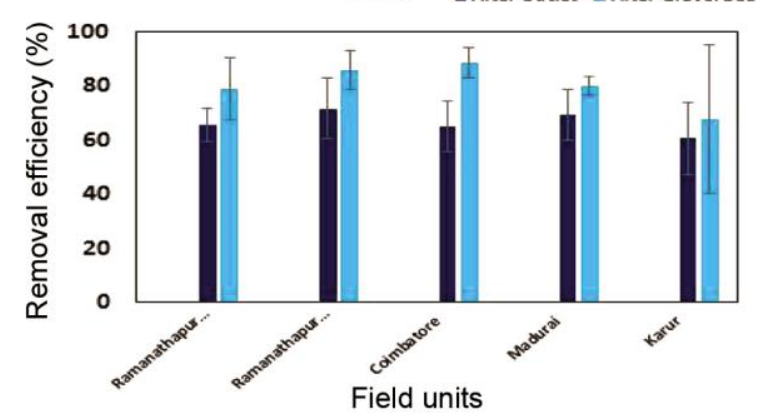

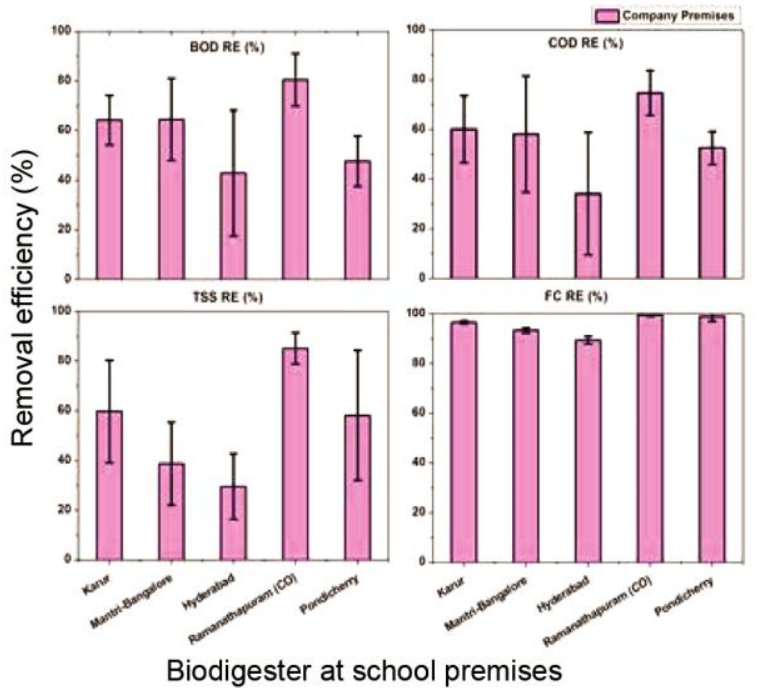

Biodigester at school premises
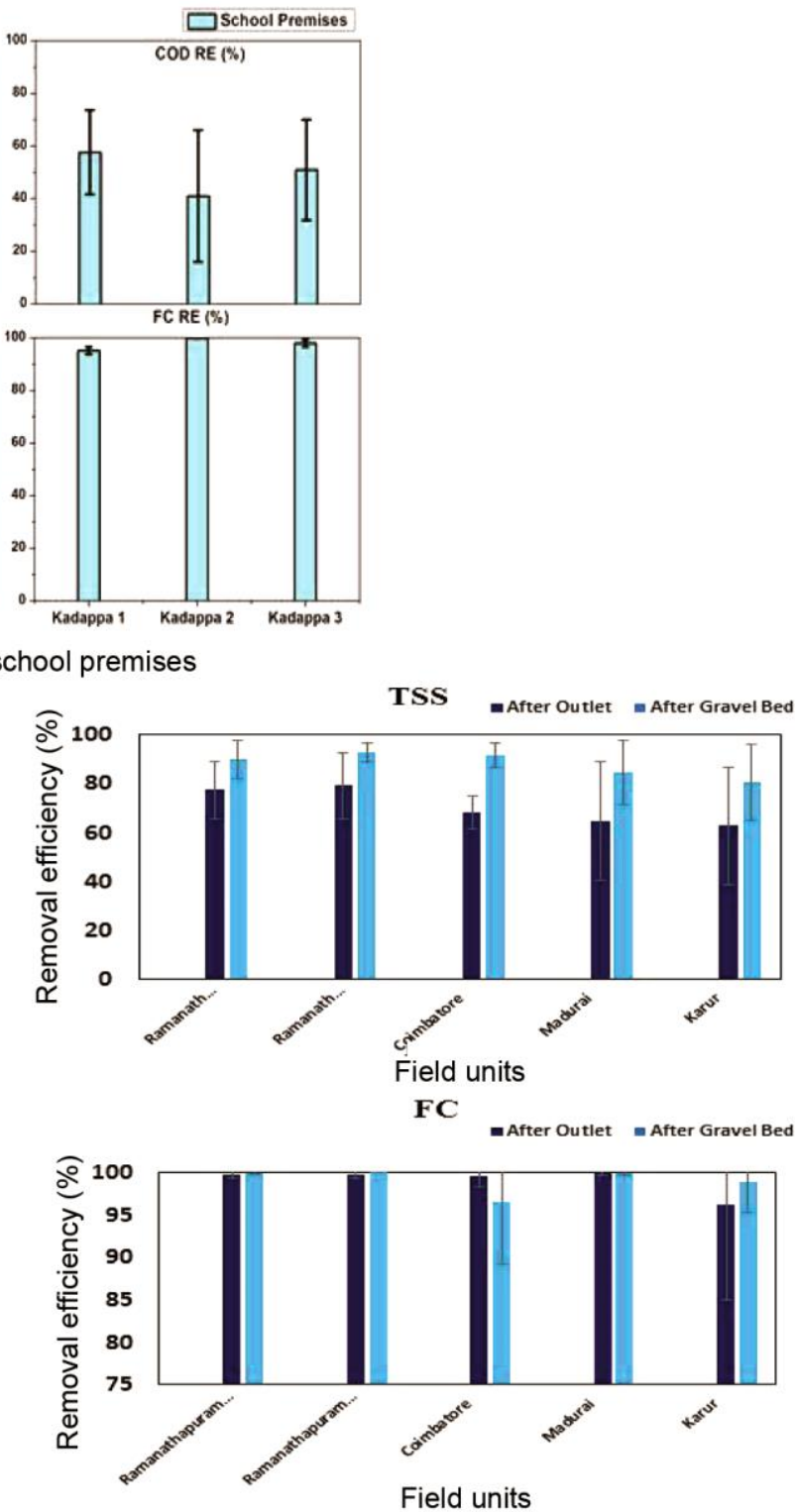

Figure 2(Continued). $\quad c$, Depending on the type of establishment. $\boldsymbol{d}$, Sampling after biodigester and after the post treatment unit. 
complex biochemical pathway. TSS was a visual indicator of suspended organic and inorganic pollutant load and its removal showed the settleability of solids in the digester. Even though there was large fluctuation in influent concentration, the treated water characteristics did not vary significantly throughout the study. The average HRT found in the field units was in the range 3-10 d. However, this variation did not show significant impact on COD removal efficiency. After the treatment, 3log reduction of FC was obtained. According to Colon et $a l .{ }^{24}$, the substantial reduction of FC in anaerobic treatment was due to the combined mechanism of physical (adsorption into the suspended solids) and biological processes (natural die-off of microbes). The removal efficiency observed in this study was comparable with other studies using anaerobic packaged systems, UASB reactors and baffled septic tanks with anaerobic filter. Sharma and $\mathrm{Khazmi}^{11}$ used a filter-based packaged system for treating source-separated black water and achieved a removal efficiency of $72.6 \%$ in terms of COD and $83.2 \%$ in terms of BOD. De graff et ll $^{25}$ reported that the UASB reactor treating black water at an $\mathrm{HRT}$ of $7 \mathrm{~d}$ and at a temperature of $25^{\circ} \mathrm{C}$ achieved removal efficiency of $73 \%$. Grab and composite sampling results (BOD, COD and TSS removal efficiencies) were compared (Figure $2 b$ ). Variations between grab and composite samples were observed in all the sites. The sites with regular number of users showed higher difference in BOD, COD and TSS removal, in the range $11-34 \%, 11-18 \%$ and $18-44 \%$ respectively (Figure $2 b$ ). FC removal difference was observed to be less than $1 \%$ for all the sites while performing grab and composite sampling. The composite sampling showed an estimated average value over a $24 \mathrm{~h}$ period, whereas grab sampling showed the value of samples at a particular point and time. Due to higher fluctuation in influent organics and solids concentration, grab sampling from the first compartment was not considered as a representative method for sample collection for the anaerobic baffled biodigester whereas, it was suitable for the treatment systems where waste water was well mixed, and had consistent influent flow rate and characteristics. Moreover, composite sampling reduces data uncertainty considerably when compared to grab sampling ${ }^{26}$. Thus the present study recommends the use of composite sampling for characterizing the nature and magnitude of the discharge pattern. In addition, performance of the biodigesters installed by different vendors was studied. It was observed that there was no significant difference in the performance of these anaerobic biodigesters. Detailed information is presented in the Supplementary Material (Section 3).

\section{Performance based on type of establishment}

The black water characteristics based on the type of establishment is discussed below. Figure 3 shows the average influent BOD and COD concentrations of the digesters installed in community toilets, company toilets and school toilets. The organic loading rate of digesters in the community, company and school toilets was in the range $0.6-2.19,0.8-1.6$ and $0.4-1.1 \mathrm{~kg}$ COD/d respectively. The higher variation is due to variability in the number of users, amount of faeces coming in and water usage by the people. The influent solids concentration at the community, company and school toilets was in the range 493-945, 370-1183 and 259-423 mg/l respectively. Fluctuation in organics loading and solids concentration in different localities was due to the lifestyle of the users. It was observed that biodigesters installed in the school toilets showed lower organics concentration than those in the community and company toilets (Figure 3), since toilets in the schools are generally used as urinals. The influent organics concentrations in the community toilets and biodigesters in the company premises are in good agreement with the values reported by Hocaoglu, and Henze and Ledin, whereas biodigesters in the school premises showed slightly lower values than those reported. The average FC concentration of inlet water was in the range $3.5 \mathrm{E}+7-3.7 \mathrm{E}+8,4.3 \mathrm{E}+7-3.5 \mathrm{E}+8$, 2.5-3E+7 MPN/100 $\mathrm{ml}$ for the community, company and school toilets respectively. During the entire study period, FC concentration range in influent was consistent for all the localities. Figure $2 c$ shows the removal efficiency of organics, solids and pathogens for the biodigesters at different localities. The biodigesters at the school premises achieved removal efficiencies of BOD, COD and TSS in the range of $60-65 \%, 50-58 \%$ and $45-50 \%$ respectively. Biodigesters connected with community toilets achieved BOD, COD and TSS removal in the range 65-70\%, 55$60 \%$ and $60-70 \%$ respectively. The removal efficiency of BOD, COD and TSS was in the range 60-65\%, 50-55\% and $60-70 \%$ respectively, for biodigesters at the company premises. The presence of sludge particle was observed in treated water from the digester at the school premises, which indicates sludge wash-out in these biodigesters. This in turn increased the COD and TSS concentration of treated water. As a result, removal rate was comparatively lower than the biodigesters at the community and company premises. It was also observed that the sludge washout was mainly due to higher influent flow rate, which lead to shorter HRT. This resulted in less stabilized sludge due to lower percentage of hydrolysis ${ }^{27}$. According to an earlier study by Munoz et $a l .{ }^{28}$, an increase in HRT may improve COD and nitrogen removal. However, the present study, HRT of 5, 7 and $10 \mathrm{~d}$ showed similar treatment efficiency in terms of organics and solids removal. The higher reactor capacity with less influent flow rate and lower organics loading resulted in higher HRT. Also, it had been observed that the flow rate of influent varied in the field sites based on the number of users. Though FC removal efficiency was observed to be $95 \%$ in all the sites, the treated effluents did not meet the 
(a)

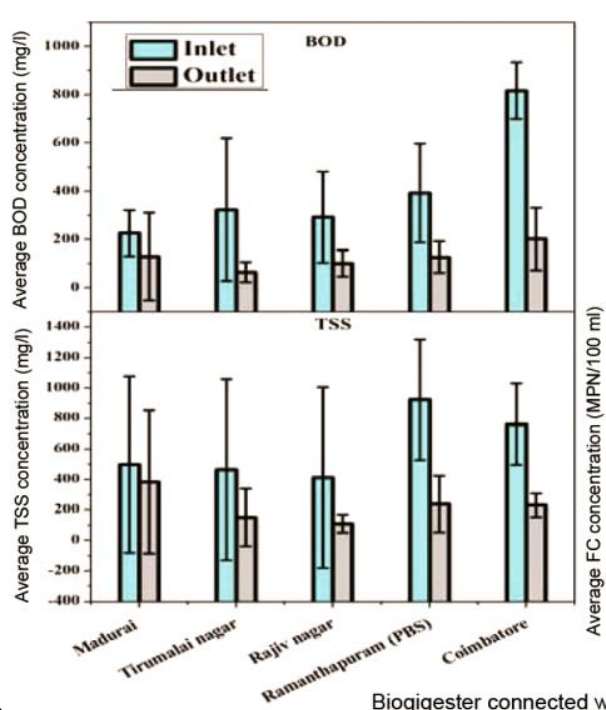

(b)

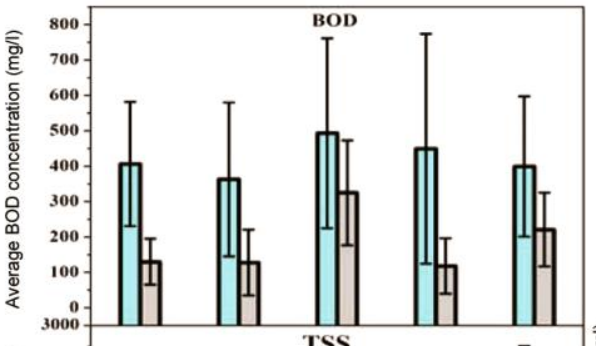

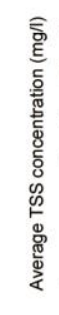

(c)
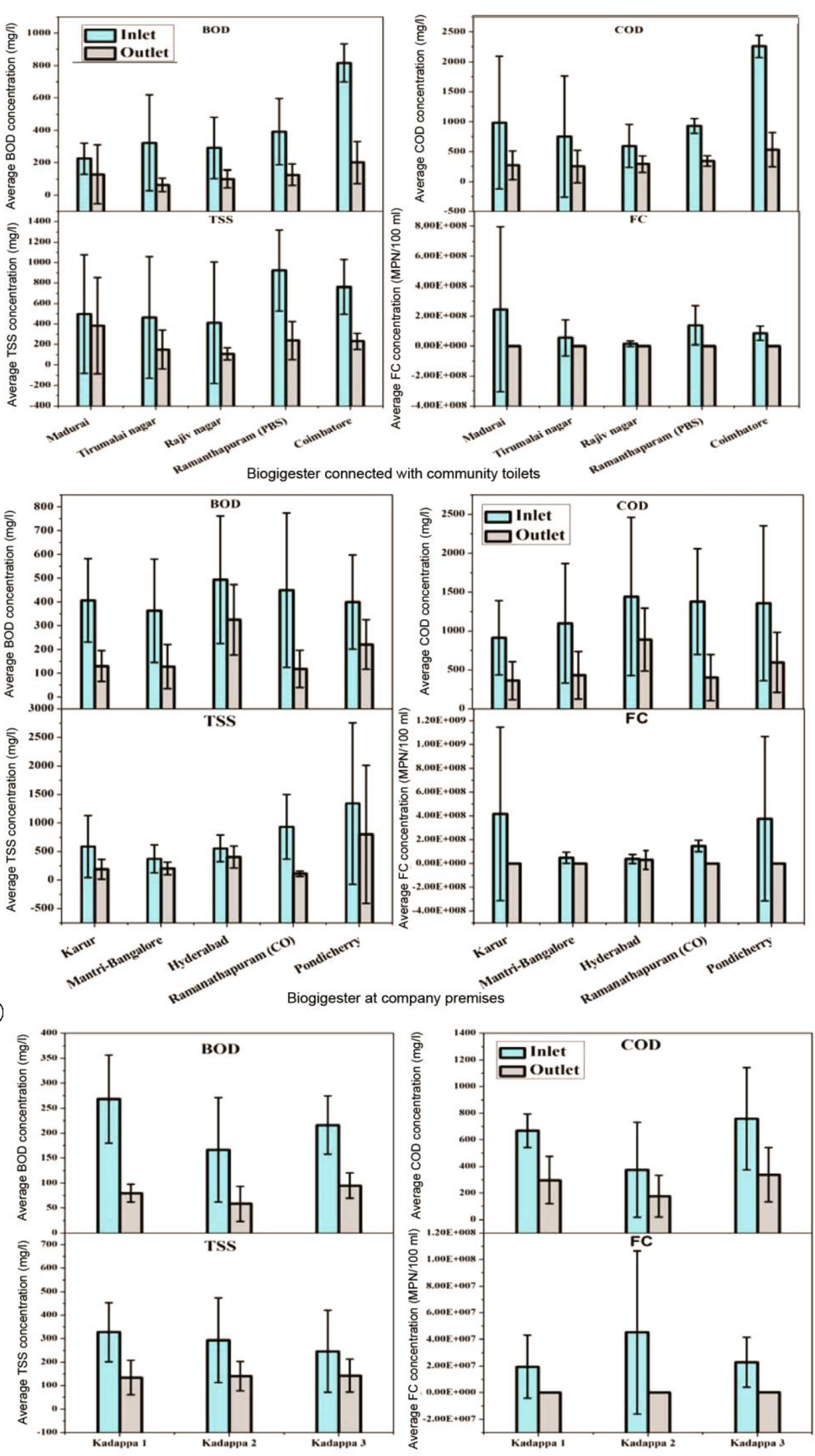

Biodigester at school premises

Figure 3. Average concentration of BOD, COD, TSS and FC of anaerobic baffled biodigester at different establishments. (a) community toilets, $(\boldsymbol{b})$ company toilets and $(\boldsymbol{c})$ school toilets. 
effluent discharge standards prescribed by Central Pollution Control Board (CPCB) ${ }^{29}$.

\section{Contribution of post treatment units in effluent quality}

The removal efficiencies of biodigester and biodigester with post-treatment units were compared (Figure $2 d$ ) to evaluate the effectiveness of post-treatment units in the removal of residual organics, solids and pathogens. The results indicated that the biodigester followed by posttreatment unit (gravel bed) could further increase the removal efficiency by $15-20 \%$ for COD (Figure $2 d$ ), 10 $15 \%$ for BOD and $10 \%$ for solids. Thus, biodigesters with post-treatment units showed better performance in terms of organics and solids removal when compared with the units that had only biodigesters for treating black water. Thus, the combination of anaerobic baffled biodigester with post-treatment unit will able to achieve better treatment efficiency in case of black water. The findings were in agreement with previous studies. Nguyen et al. ${ }^{30}$ examined baffled septic tank with and without anaerobic filter for black water treatment in Vietnam. They reported that the treatment system without post-treatment effectively achieved $74.85 \%$ COD and $71.47 \%$ BOD removal. However, this treatment system was not able to meet the wastewater discharge standards in Vietnam. Therefore, the authors studied the post-treatment performance of BASTAF effluent with a vertical flow constructed wetland and achieved 10\% improvement in organics and solids removal, which is comparable to the results obtained in the present study. Other studies reported higher removal efficiencies for treatment systems such as anaerobic packaged systems ${ }^{31}$ and UASB-septic tanks ${ }^{12}$ compared to conventional septic tank. However, these systems also could not fulfil the prescribed disposal standards for wastewater. Hence, the present authors emphasize the need for post-treatment after anaerobic treatment system. Moreover, the post-treatment (reed bed and gravel bed) unit after bio-digester removed residual organics and solids effectively. Hence, proper maintenance of such units is recommended to achieve efficient treatment in such on-site treatment systems. To achieve the desired effluent quality for reuse, constructed wetlands or reed beds are recommended as an option for post-treatment. Any submerged attached growth aerobic biological system followed by dual media filtration process also can produce the desired quality of effluent, for various reuse purposes.

In the case of FC removal performance, the gravel/reed bed was inefficient in achieving significant improvement. If the treated water is to be reused, chlorination or some alternative disinfection system is indeed for pathogen removal. The samples collected before and post-treatment showed a consistent $3 \log$ reduction of FC. Though it showed $99 \%$ removal, it did not comply with the Indian disposal standards for treated wastewater. Hence, additional disinfection systems are needed for the removal of FC. Moreover, improvement in the removal of organic matter and nutrients by the post-treatment units was mainly because of filtration and cleaning processes due to biological activity in the biofilm attached on the gravel/sand. Thus, the results of the present study show that the performance of anaerobic baffled biodigesters varies based on the number of toilets users these were attached to, the frequency of usage, location of the toilets, purpose of use, sample-collection points and posttreatment units installed after the biodigesters.

\section{Conclusion}

The performance of existing anaerobic baffled biodigesters installed in different regions of south India was evaluated in terms of organics, solids and pathogens removal. There was no significant difference observed between performances of anaerobic biodigesters installed by different DRDO licensee vendors in South India. The study results confirmed that grab and composite sampling method showed percentage variation of organics and solids in influent. Units with regular usage performed better, i.e. among the 13 sites studied, those with regular number of users showed higher COD removal efficiency in the range of $70-75 \%$ and BOD removal efficiency at about $50-60 \%$. Even though FC removal efficiency was around $95 \%$ in all the sites, the treated effluents did not meet the CPCB standards. Presence of reed bed/gravel bed enabled better outlet quality compared to systems employing only the biodigesters. The results of the present study indicate that the characteristics of the treated water depend upon the usage of toilets, amount of faeces coming in, the number of users, location and post-treatment units installed after biodigesters.

1. Lindley, S. T., Estimation of population growth and extinction parameters from noisy data. Ecol. Appl., 2003, 13, 806-813.

2. Martin, H., The Archaean grey gnesisses and the genesis of continental crust. In Archaean Crustal Evolution (ed. Condie, K. C.), Elsevier, Amsterdam, The Netherland, 1994, pp. 205-259.

3. Rao, K. N. and Vaidyanadhan, R., Geomorphic features in Krishna Delta and its evolution. In Proceedings of the National Symposium on Morphology and Evolution of Landforms, Department of Geology, Delhi University, New Delhi, 1978.

4. WHO/UNICEF Joint Water Supply and Sanitation Monitoring Programme, 2014. Progress on drinking water and sanitation: 2014 update. World Health Organization.

5. Jin, Z. et al., Black water collected from the septic tank treated with a living machine system: HRT effect and microbial community structure. Chemosphere, 2018, 210, 745-752.

6. Medilanski, E., Chuan, L., Mosler, H. J., Schertenleib, R. and Larsen, T. A., Wastewater management in Kunming, China: a stakeholder perspective on measures at the source. Environ. Urban., 2006, 18, 353-368.

7. Larsen, T. A. and Gujer, W., Separate management of anthropogenic nutrient solution (human urine). Water Sci. Technol., 1996, 34, 87-94. 


\section{RESEARCH ARTICLES}

8. Sasse, L., DEWATS: decentralised wastewater treatment in developing countries. Bremen Overseas Research and Development Association, Germany, 1998.

9. Lutterbeck, C. A., Zerwes, F. V., Radtke, J. F., Köhler, A., Kist, L. T. and Machado, E. L., Integrated system with constructed wetlands for the treatment of domestic wastewaters generated at a rural property - evaluation of general parameters, ecotoxicity and cytogenetics. Ecol. Eng., 2018, 115, 1-8.

10. Sabry, T., Evaluation of decentralized treatment of sewage employing upflow septic tank/baffled reactor (USBR) in developing countries. J. Hazard. Mater., 2010, 174, 500-505.

11. Sharma, M. K. and Kazmi, A. A., Anaerobic onsite treatment of black water using filter-based packaged system as an alternative of conventional septic tank. Ecol. Eng., 2015, 75, 457-461.

12. Zhou, J., Wang, X. C., Ji, Z., Xu, L. and Yu, Z., Source identification of bacterial and viral pathogens and their survival/fading in the process of wastewater treatment, reclamation, and environmental reuse. World J. Microbiol. Biotechnol., 2015, 31, 109-120.

13. Ladu, J. L. C. and Lü, X. W., Effects of hydraulic retention time, temperature, and effluent recycling on efficiency of anaerobic filter in treating rural domestic wastewater. Water Sci. Eng., 2014, 7, 168-182.

14. Bodik, I., Kratochv, L. K., Gaparikov, E. and Hutan, M., Nitrogen removal in an anaerobic baffled filter reactor with aerobic posttreatment. Bioresour. Technol., 2003, 86, 79-84.

15. Luostarinen, S., Sanders, W., Kujawa-Roeleveld, K. and Zeeman, G., Effect of temperature on anaerobic treatment of black water in UASB-septic tank systems. Bioresour Technol., 2007, 98, 980 986.

16. Langenhoff, A. A. and Stuckey, D. C., Treatment of dilute wastewater using an anaerobic baffled reactor: effect of low temperature. Water Res., 2000, 34, 3867-3875.

17. Manariotis, I. D. and Grigoropoulos, S. G., Low-strength wastewater treatment using an anaerobic baffled reactor. Water Environ. Res., 2002, 74, 170-176.

18. Kumar, G. S., Kar, S. S. and Jain, A., Health and environmental sanitation in India: issues for prioritizing control strategies. Indian J. Occup. Environ. Med., 2011, 15, 93.

19. American Public Health Association (APHA) (2012) Standard method for examination of water and wastewater, 18th edn. American Public Health Association, Washington DC.

20. Ramana, K. V., Tomar, A. and Singh, L., Effect of various carbon and nitrogen sources on cellulose synthesis by Acetobacter xylinum. J. Microbiol. Biotechnol., 2000, 16, 245-248.
21. DRDO FICCI, Accelerated technology assessment and commercialization, 2014; http://drdoficciatac.com/biodigester/ aboutus.asp.

22. Kujawa-Roeleveld, K. and Zeeman, G., Anaerobic treatment in decentralised and source separation-based sanitation concepts. Rev. Environ. Sci. Bio/Technol., 2006, 5, 115-139

23. Hocaoglu, S. M., Insel, G. and Cokgor, E. U., COD fractionation and biodegradation kinetics of segregated domestic wastewater: black and grey water fractions. J. Chem. Technol. Biotechnol. 2010, 85, 1241-1249.

24. Colon, J., Aaron, A., Forbis-Stokes and Deshusses, M. A. Anaerobic digestion of undiluted simulant human excreta for sanitation and energy recovery in less-developed countries, Energy Sustain. Dev., 2015, 57-64.

25. DeGraaff, M. S., Zeeman, G., Temmink, H. and Buisman, C. J. N., Anaerobic treatment of concentrated black water in a UASB reactor at a short HRT. Water, 2010, 2, 101-119.

26. Tchobanoglous, G., Burton, F. L. and Stensel, H. D., Wastewater Engineering: Treatment, Disposal, Reuse, Metcalf and Eddy, Inc., New York, USA, 2003.

27. Voorthuizen, E., Zwijnenburg, A., van der Meer, W. and Temmink, H., Biological black water treatment combined with membrane separation. Water Res., 2008, 42, 4334-4340

28. Munoz, M. A., Rosales, R. M., Gabarron, M., Faz, A. and Acosta, J. A., Effects of the hydraulic retention time on pig slurry purification by constructed wetlands and stabilization ponds. Water, Air, Soil Pollut., 2016, 9, 227-293.

29. CPCB, MoEFCC draft notification, Central Pollution Control Board, New Delhi, 2015.

30. Nguyen, A. V., Pham, N. T., Nguyen, T. H., Morel, A. and Tonderski, K., Improved septic tank with constructed wetland, a promising decentralized wastewater treatment alternative in Vietnam. In NOWRA 16th Annual Technical Education Conference and Exposition, Hanoi, 2007, pp. 1-17.

31. Schaeffer, D. J., Kerster, H. W. and Janardan, K. G., Grab versus composite sampling: a primer for the manager and engineer. J. Environ. Manage., 1980, 4, 157-163.

ACKNOWLEDGEMENTS. This study was supported by a research fund from STeP, the Sanitation Technology Platform, managed by RTI International, USA

Received 17 October 2019; revised accepted 23 January 2020

doi: $10.18520 / \mathrm{cs} / \mathrm{v} 118 / \mathrm{i} 8 / 1265-1274$ 